\title{
Students' Perceptions toward a Conversational Class Taught By Foreigner Counterpart
}

\author{
Nurul Inayah \\ English Department of Educational Faculty \\ State Islamic Studies Institute (STAIN) Salatiga \\ Jl. Tentara Pelajar No. 02 Salatiga, Central Java, Indonesia \\ Nurulinayah_aiu@yahoo.com
}

\begin{abstract}
This research is aimed at knowing what the students' perception of having taught by foreigner counterpart (native speaker of English) in a conversational class. Besides elaborating the students' perception which affects how they act and behave during the teaching and learning process, this research also wants to explore the students' difficulties and strategies in facing the foreigner's class. Then, the students' expectation of an ideal conversational class is also important to be investigated in order to conduct a better one in the future. Since this research explores the students' perception which come from the students' experience, qualitative approach is considered as an appropriate research design. Then the result of this research is presented descriptively in order to reveal the students' perception comprehensively. The findings of this research show that most of the students give high appreciation with the presence of foreigner. In fact, the personality of the foreigner as a teacher is also very important to be highlighted since it gives significant influence on students' perception. The personality and skill in classroom management become reasons for the other students who do not like the foreigner. Then, the cross cultural understanding and the ability to communicate in English is the students' main difficulty that hinders their teaching and learning process.
\end{abstract}

Keywords: Perception, Conversational Class, Foreigner Counterpart 


\begin{abstract}
Abstrak
Penelitian ini bertujuan untuk mengetahui persepsi siswa setelah diajar oleh guru asing (penutur asli bahasa Inggris) dalam kelas percakapan. Selain memaparkan persepsi siswa yang mempengaruhi bagaimana mereka bersikap dan berperilaku selama proses belajar mengajar, penelitian ini juga mengeksplorasi kesulitan siswa dan strategi menghadapi guru asing. Ekspektasi siswa terhadap kelas percakapan yang ideal juga penting untuk diteliti untuk pembelajaran yang lebih baik di masa depan. Karena penelitian ini mengeksplorasi persepsi siswa yang berasal dari pengalaman siswa, pendekatan kualitatif dianggap sebagai pendekatan yag tepat. Kemudian hasil penelitian disajikan secara deskriptif untuk mengungkap persesi siswa secara komprehensif.Temuan dari penelitian ini menunjukkan bahwa sebagian besar siswa memberikan apresiasi yang tinggi terhadap keberadaan guru asing.Pada kenyataannya, kepribadian dari guru asing juga sangat penting untuk diperhatikan karena hal ini memberikan pengaruh yang penting terhadap persepsi siswa.Kepribadian dan keahlian dalam memanajemen kelas menjadi alasan bagi siswa untuk menyukai atau tidak kehadiran guru asing. Kemudian masalah pemahaman budaya dan kemampuan berkomunikasi dalam bahasa Inggris adalah kesulitan utama yang menghambat proses belajar mengajar.
\end{abstract}

Kata Kunci: Persepsi, Kelas Percakapan, Guru Asing

\title{
Introduction
}

Providing an appropriate stimulus in the foreign language teaching and learning process would be very critical for triggering the learners to be able in using and practicing the language actively. This kind of condition is needed to create an atmosphere where both teacher and learners can interact well during the class. Unfortunately, it is difficult enough to find this kind of teaching and learning process, especially in English one, since the role of teacher does not seem to provide sufficient 
feedback for the learners. As the result, the students' abilities, mostly in oral skill could not be explored well.

Giving the opportunity for foreign language learners to actively use the language to communicate in a variety of teaching and learning activities is an effort that can be taken to overcome this problem (Pringgawidagda, 2002: 34-40). Furthermore, Pringgawidagda (2002) denoted that native speaker could strength in develope learners' ability. Similar opinion was also expressed by Stern (1992) who states that the presence of native speakers in the class will help foreign language learners to understand the thinking and feelings of the people who use the target language. Besides improving students' motivation and interest, a native speaker is also a source of accurate information in language learning as well as culture.

Seeing this kind of fact, many schools are trying to bring in native speakers in the classroom, as SMA Muhammadiyah (Plus) Salatiga. However, in this case the native speakers will be referred as an English foreigner counterpart, i.e. someone who uses English as the second language. The role of the foreigner counterpart is expected to be as maximal as a native speaker. Therefore, SMA Muhammadiyah (Plus) Salatiga itself has a conversational class which is taught by a foreigner counterpart for its first year students. It hopefully can be a facilitator to develop the students' ability to use or practice the language in the process of communication that can be understood by others. So, from this point the aim of communication can be achieved.

Absolutely, the success of class with a foreigner counterpart cannot be generalized to all of teaching and learning process. Beside all of his 
strength, a native speaker or foreigner counterpart also have some weaknesses. They may not be always conscious of his own language, more focused on verbal skills, more tolerant of errors and less stringent, and can be difficult for students in the initial learning phase (Stren: 1992). His presence can also be difficult, especially if the foreigner counterpart cannot speak the local language and the learners are not familiar with target language at all. This condition seems bringing various responses from the students as well as the first year students of SMA Muhammadiyah (Plus) Salatiga.

From the interview with the foreigner counterpart, the class having 30 students has different responses. Students may be very enthusiastic during the class through pay attention and give good participation. However, it does not work for the others. Many students do not really care of this class. They are talking to the others during the class; not paying much attention and playing with their gadget instead. Some also usually come late. The first fifteen minutes is wasted for waiting for the students. Even, some appear after thirty minutes. The foreigner tries to warm the class up by giving different method of teaching. Sometimes it is done inside the class with making group work and letting the students work alone to present a result in the end in front of the class, and in the other time they just go out somewhere outside the class or only play games. Unfortunately, some of them still do not do well during the class.

These various responses are affected mostly by the students' perception of the foreigner counterpart itself, the conversational class, and their own capability and confidence. Since perception influences the individual's action and behavior towards an object, it will be a useful 
basis to identify the students' attitude toward the class, their contributions in learning and their own behavior that might hinder the learning process. This perception also can be developed to improve the quality of learning, primarily which is taught by foreigner counterpart.

\section{Perception}

Ade diwura and Bada Tayo (2007) in their academic journal elaborate the theories of perception by taking some experts' explanation. First, they take the theories as postulated by Allport (1966) who defines perception as the way people judge or evaluate others. The second, Eggen and Kauchak theories (2001) see perception from the cognitive dimension as the process by which people attach meaning to experiences. It means that the perception comes after people attend to certain stimuli in their sensory memories. However, perception will influence the information that enters working memory. This theory is strengthened by the next statement from Glover et al. (1990). They state that background knowledge in the form of schemas affects perception and subsequent learning. Even, research findings have verified that background knowledge resulting from experience strongly influence perception. Finally, Baron and Byrne (1991) explain it as the process through which people attempt to understand other persons and attempt to obtain information about the temporary causes of others' behavior, for example, the emotions or feelings.

\section{Foreigner's role in English teaching}

Foreigner is a person belonging to owing allegiance to a foreign country or something originally in other country (Webster: 1981:889). The term foreigner counterpart in this study means someone who uses 
English as his second language and has role in the conversational class in SMA Muhammadiyah (plus) Salatiga to help improving the students' English skill.

\section{Research Methodology}

The research was conducted at SMA Muhammadiyah (Plus) Salatiga, Central Java, Indonesia. The object of the research were students of class $\mathrm{XA}$ and $\mathrm{XB}$. The primary data source was the result of interview between the researcher and the students. Then, documentation and some information from the foreigner and English teacher of SMA Muhammadiyah (plus) Salatiga became the secondary data source. The analysis followed Miles and Huberman (1992: 18-20), namely gathering data, data reduction, data presentation, and conclusion.

\section{Discussion}

Students' perception toward the foreigner as the teacher

There were various opinions as the result of the interview process since this research explores the students' thought and perception toward their experience in having taught by foreigner counterpart personally. Each student had their own point of views. However, in general it could be classified into: appreciative, neutral, and hateful

\section{Appreciative}

Having taught by foreigner might be the first experience for some students. They were very excited to have an uncommon chance where they could directly interact with the foreigner. This positive appreciation could be seen as follows. 
(1): "Yaaa gimana ya ... ya cukup memberi pengalaman baru bagi kami semua, temen-temen. Ya menarik lah. (I think it is a new experience for us. So, it is interesting)"

(2):"Eee seneng banged ya, karena jarang banget bisa ketemu sama bule terus langsung bisa berinteraksi langsung gitu. (I am very glad, because it is a rare opportunity to meet and interact with the foreigner directly)"

( 3): “... Awal-awal tu kayak yang gimana ya, heran gitu 'waaah orang luar, gini gini' (At the early time I was very excited 'wow foreigner')

In general, some students liked the foreigner because of either his personality or his methods in teaching. E2, G2, and R2 for example, they looked the foreigner as a very kind, friendly, humble and humorous person. He sometimes also taught in fun activities through some games. The following data express the appreciation toward the foreigner.

(4): 'Ya. Sebenernya suka, orangnya low profile, lucu, cara pengajarannya juga menarik gitu. (I like it. He is low profile and humorous person. His teaching methods are also interesting)

(5): "Itu ga terlalu mengarah ke pelajaran, jadinya cuma kayak permainan-permainan gitu, nambah-nambah vocab gitu. (It is not about the lesson at all but tends to games to enrich vocabularies)"

(6): "Ee..lumayan asyik terus juga inovatif jadi buat game apa apaa gitu jadi kadang ada cerita terus suruh buat.. pernah suruh buat komik pake bahasa inggris, terus apa lagi ya? Eem ada drama juga pake bahasa inggris terus itu juga ada 
pengenalan tentang Jerman eee itu, asal dari $J$ itu sendiri.(Ee... fun and innovative. There are games, telling stories, and making comic in English. What else's? Eeem making drama in English and introducing his country, German)"

\section{Neutral}

The term 'neutral' in this paper refers to a condition where the students neither look at the foreigner as the special one nor underestimate them. For very few students, the presence of foreigner was not special thing.

(7): “Biasa aja. (Just so-so)"

As confirmed by the student, foreign teacher or Indonesian one was not a problem. Whoever the teacher, he highlighted that the more crucial thing was how the teacher could bring fun teaching to the class.

Some students could not define it as a special thing because the teaching and learning process was influenced by some factors, for example the methods and materials. Some of them only liked it in particular activity.

(8): "Ya kadang-kadang ada sukanya kadang-kadang ada enggaknya... Misalnya kalau pas games-games gitu, seneng. (Sometimes I like it especially when it is game but in other time I don't)"

(9): "Ya suka kan soalnya ada permainan-permainan kita kan bisa fresh gitu, pengennya bersantai. Tapi enggak sukanya itu dia itu kalo di ajak konsentrasi tu kurang trus dia kalo di ajak bercanda itu kurang gitu lo mb...(I like it because through games we can refresh our mind. But I don't like it when it is 
difficult to make a joke with him or simply ask him to more concentrate...)"

\section{Hateful}

The term 'hateful' in this case does not mean that the students hate the foreigner at all. It is used to describe disliking because of some reasons. Actually like or dislike is such of felling that cannot be measured with a particular tool. However, this category appeared from the students' information and reasons which clearly showed their disliking. The first reason was communication problem. A few students admitted that they disliked having taught by the foreigner because of this problem.

(10): "Berbeda ya, soalnya dari segi komunikasi mungkin kita lebih nyaman sama guru biasa. (It is different. We feel more comfortable when communicate with non native teacher)"

(11): “Jujur, ga seneng mbak. Kata-katanya kurang jelas owg mbak. (To be honest, I don't like it. I cannot understand his words)"

(12): “...Lebih suka diwulang guru sendiri lebih masuk daripada orang lain. (...I prefer having taught by Indonesian teacher to the foreigner, because it is more understandable)"

Besides the communication problem, the personality of the foreigner also became the second reason to dislike the foreigner. All of the students included the appreciative ones agreed that the foreigner was 
quick-tempered person. When be confirmed by the interviewer, his anger usually caused by the noisy class.

(13): "Naa ini yang saya sedikit tidak suka. Dia itu orangnya agak sensitive sama... kadang agak putus asa gitu ketika kelasnya sudah tidak kondusif, gitu. Yaaa kalo orang jawa bilang mutungan gitu loo, trus 'terserah kalian' gitu.(Actually I do not like this one thing. I think he is a 'sensitive' person who is hopeless when the class changes into unconducive one. Javanese says 'mutungan' (angry), then he does not care anymore)"

(14): "Ya tapi suka marah-marah. Kalau, biasanya kan anak-anak kan jail gitu, sering rame lah. Biasa gitu ya. Ya sering marahmarah gitu. (He is temperamental person. When the students are noisy, he will be angry)

Then, the third reason was admitted by the students regarding the less ability of the foreigner to manage the class well. The poor classroom management triggered indiscipline behavior in the class, such as did not pay attention, chatted with their friends, or simply just played with their gadget instead, as confirmed by the foreigner itself. From the students' perception this condition was a responsibility that the teacher had to take. It could be showed from the data bellow.

(15): "Nggak sukanya sama orangnya mbak. Hehehhehe. Dia itu kayak emosian gitu. Padahal itu karena kesalahan yang dia buat karena dia tidak bisa menguasai (kelas).(I do not like his personality. Hehehehe. He is a temperamental person. In fact, it is his own mistake if he cannot manage the class well.)"

(16): “Ada sih alesannya itu gara-gara yang di ajar itu ga memperhatikan sama dia. Tapi kalo saya sebagai murid lebih 
memandang kalau dia tidak bisa menguasai kelas gitu..(There is a reason why he is getting angry: because we do not pay attention to him. But as a student I think it is caused by his poor classroom management)"

At the beginning meetings, toward the noisy class, the foreigner kept silent and waited the class to be conducive.

(17): "Pada waktu awal-awalan banyak yang gojek sendiri ga dimarahin. (At the beginning, he lets the students do indiscipline behavior in the class)" (L2.43)

However, facing the bad atmosphere in the class made him start to warn the students. To warn the students, he used high intonation and sometimes pounds on the table. He never gave any kind of punishment or benches the students from the class.

(18): 'Seperti mungkin menggebrak meja, 'Hey c'mon guys' gimana gitu. Kalau menghukum, ga! (He pounds on the table and says 'Hey c'mon guys', something like that. But he never gives punishment) (A2.13-A2.14)

Unfortunately, this way gave bad perceptions from the students that made them dislike the foreigner's class. In the fact, that kind of warning was not an effective way to realize a conducive class. As confirmed by some students, they would keep silent for a while when they were warned by the foreigner. However, they would make a noisy again soon.

(19): "pertama-tama diem trus gojek lagi. (We keep silent first but then we make a noisy again)" (N2.20)

(20): "Yaa biasanya diam dulu tapi karena ya mungkin banyak yang tidak apa, tidak ngeh gitu apa yang dia katakan jadi 
ya.... Ngobrol-ngobrol lagi. (We keep silent for a while. But because we do not understand his words I think, so we start to make a noisy again)" (M2.14)

\section{Students' perception toward the conversational class}

Students' perceptions toward their own conversational class were measured from the ways they looked at the situation of the class. It was also related with the interaction between the foreigner and the students during the class, the methods, and the materials/themes given by the foreigner.

\section{Class situation}

The interview process showed that the situation in the conversational class could be classified into fun, bored and strained situation.

First, for the enthusiasm and active students the situation in the conversational class was fun. This fun learning was strongly influenced by the various methods and materials during the class.

(21): "Menyenangkan. (It is fun)"

Second, the situation in the class turned to be bored when the foreigner was monotone in explaining the materials, to be too serious, less interaction with the students, or in bad mood.

(22): "Membosankannya waktu dia menyampaikan materi itu sih.(It is bored when he explains the materials)"

(23): "Kalau saya ya bosen lah. Kalau kan sabtu sekarang, saya bolos. Soalnya dia itu menjelaskannya itu seringnya bagaimana ya... cuma teori kalau tidak interaksi dengan siswa itu kan siswa juga bingung mau ngapain jadi semuanya 
bingung. (It is bored I think. The schedule is on Saturday now and I play truant from the class. Because I think he explains in ee... I mean if he only explains the theories without any interaction with the students I think it make us confuse about what we have to do)"

(24): "ya biasanya itu, dia itu orangnya tergantung mood.Kalo moodnya lagi jelek gitu ya kelasnya jadi bosan, dia agak gimana gitu.(He is a moody person. If he is in bad mood, the class will be bored)" (M2.16)

Third, few students said that the class was strained because the foreigner only spoke in English. They did not enjoy the class since they could not interact and communicate well.

(25): "Mungkin ya agak menegangkan ya mbak. Kan situ apa, berbicaranya pakai bahasa inggris kita kan ga mudeng jadi cuma meneeeeng terus. Kita kan apa, kalau sedikit-sedikit pakai bahasa Indonesia kan kita tau. Tapi kan situ kan menerangkannya tu pakai bahasa Inggriiiiiiiiis trus kan kita jadi tegang.(Maybe it is a little bit strained. He always speaks in English whereas we do not understand it so we just keep silent. If he speaks little in Bahasa Indonesia we may understand it. In fact, he only speaks in English so we feel so strained)".

Beside the fun, bored and strained situation, there was a confession from a student that the presences of active students give significant effects. In fact, the situation in the class was not only influenced by teacher's factor. These students were admitted can create good atmosphere to the class. 
(26):"Tergantung ya mb kalo yang kayak amalia, rosyad ikut gitu lebih ramai. Tapi kalo yang ikut cuma, maaf ya yang agak ga mudeng gitu.Sulit untuk berkomunikasi. (It depends situation, if there are Amalia or Rosyad (active students), it will be more interesting. But, I am sorry, if it just consists of students who do not understand English, it will be very difficult to communicate)" (D2.21)

Classroom interaction

Unfortunately, not all of students could interact well during the class. Students having good competency in English might not have problem with classroom interaction. They could freely ask when they did not understand, answered the question or simply did the foreigner command. They could interact with the foreigner easily because they understood more than the others.

(27): "Eeem kalo saya pribadi itu eee paham, tetapi mungkin teman-teman saya yang kurang apa ya, ya ya kadang 'opo sih artine? Ndak mudeng' gitu.(I myself can understand it. But I think some friends cannot)"

In fact, for other students, interaction with the foreigner was not easy. They said that there was difference in interaction with the foreigner and their own teacher/Indonesian teacher. It was more comfortable for them to communicate with Indonesian teacher, as reflected in Data 11 and Data 13. It made some students passive during the class.

(28): "Beda banget mbak. Kalau guru kan biasa tapi kalau sama turis kan apalagi baru pertama ketemu gitu kan aduuuh ngomong apa ya, bingung gitu, deg-degan gitu. (There is a difference in communication with the foreign teacher. I can communicate with the Indonesian teacher easily. But with the 
foreigner, I feel a little bit confuse what I have to say. I also feel nervous)"

(29): "Gimana ya? Mungkin kalau aktifnya itu, kalau di pembelajaran foreigner saya ga terlalu aktif, tetapi kalau di pembelajarannya Bu Hesti sendiri kan saya agak terlalu mudeng jadi kan saya juga aktif gitu. (I think I am active in Indonesian teacher class, but for the foreigner's class I don't)" (I2.11)

Looking at those facts, some students considered that the foreigner only interacted with particular students.

(30): “Interaksi itu, untuk anak-anak yang tertentu saja. Enggak, enggak gitu (pilih kasih). Misalnya, dia kan dia kan juga bisa tau, dia kan juga melihat mana anak yang memperhatikan, mana anak yang mlengos yang mengacuhkan dia (naa interaksinya itu dengan anak-anak yang memperhatikan tadi). (He only interacts with particular students. It does not mean unfairly. But I mean he can see which students who pay attention and which ones who do not. (And the interaction is only with those who pay attention)"

Teaching methods

It had to be admitted that the foreigner were creative enough in giving the materials through kinds of methods. Sometime they did it in the class and in the other time they went outside. There were kind of games, quizzes, or just discussions about a particular theme.

(31): "Bervariasi.Ya membuat game, kadang dia suka diluar kelas, lapangan situ sambil duduk-duduk bebas, santai, gitu trus juga di kelas. (It uses various methods. Sometimes it is done 
outside, in the field to relax ourselves, for example. In the other time we just go inside)"

(32): "Macem-macem sih.Ya kadang-kadang tadi, kuis, lomba, kadang cuma ngajar doang.(There are many kinds of methods. It is sometimes quizzes and sometimes just explanation)"

\section{Materials/themes}

The themes or materials itself also brought a significant effect. The students enjoyed the class when they enjoyed the materials. There were some materials which were very attractive for the students. For example was the material about German and its nation.

(33): "Ya tentang itu pengetahuan waktu menerangkan tentang Jerman. (It is about German)" (B2.35)

As claimed by other student, the materials were not about the structure or grammar rules, so it was more interesting for them.

(34):"Temanya itu lebih yang ke apa, kemasyarakatan, wawasan masyarakat, ga ke semisal ga ke greeting card atau ke apa tu namanya structure gitu ga. Tapi kita itu dilatih untuk semisal wawasan AIDS, terus wawasan, pokoknya tu wawasan tentang kebiasaan kehidupan sehari-hari. (The themes are

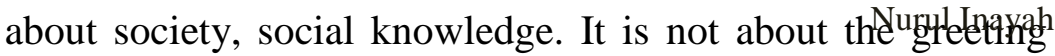
card or structure. But we are familiarized with the knowledge of AIDS, and then, the knowledge of our daily life.)"

However, a controversial material/theme appeared because of the different culture between German and Indonesia. In fact, the theme 'HIV/AIDS Prevention' got 'negative' responses. When the theme was 
delivered, a student even left the class because she thought that the content was too vulgar for senior high school students. Other students also agreed that actually this theme is inappropriate for them.

(35): “Eeem mungkin ada suatu tema yang itu agak ....Ih ....agak jorok sebenarnya (tentang HIV).Itu menurut saya ya. Saya aja kabur dari kelas. Ya, dia kan ga tau gimana Indonesia. Dia itu pernah ngomong "sex itu diperbolehkan" ... looh kan sini kan sebagai... waaah itu sesuatu yang ...(Eeem there is a theme which is... iiiih so vulgar I think (the time when he explains HIV). It makes me escape from the class. He does not know Indonesian culture. He said that sex is allowed. Oooh it be...)"

(36): "ya ada yang menarik tapi ada juga yang agak sebenarnya tidak etis untuk dibahas ya, eee yang menarik misalkan tentang Jerman itu, kami bisa ee menambah wawasan tentang negara asal beliau. Tapi kan ee pernah sekali eee temanya tentang apa, pengetahuan seksual untuk remaja. Mungkin karena budaya disana dan budaya disini agak agak jauh berbeda sehingga cara dia menyampaikan agak maaf kurang bisa diterima disini, agak kesannya tidak etis gitu. (There are interesting themes, about German for example. We know more about his motherland. But there is also a particular theme that cannot be accepted. It is about sex education for the teenagers. Maybe because the culture there (Germany) and here (Indonesia) are different, hence the way he delivered, I am sorry, is unacceptable, it seems that it is not ethical to deliver)"

Actually, the foreigner had good intention in raising the theme. HIV/AIDS prevention was a good and important theme since everyone had to be aware of it. However, the problem was on the way he explained 
it. He brought condom in the class and showed the way how to use it. $\mathrm{He}$ gave a detail description about it. Socialization about sex and HIV/AIDS for the students through that way might be usual thing in his country. However, in Indonesia, it could not be accepted. Beside of culture differences, the students from religious background of school like SMA Muhammadiyah (Plus) Salatiga were taught that free sex is prohibited. Those detail description was worried in giving a stimulus for the students to do/practice it instead. These facts made the HIV/AIDS theme got the harsh response. It forced the foreigner, Mrs. Hesti (local teacher) and the students to face uneasy or unpleasure time.

In the other side, the male students considered the HIV/AIDS as their favorite theme. They argued that when this theme was given all of students became very focus; a rare moment that could not be found in others theme. It was also claimed by $\mathrm{C} 2, \mathrm{G} 2$, and $\mathrm{O} 2$.

(37): "Itu... menurut saya itu materi yang paling banyak mendapatkan respon dari temen-temen. Yaaa mbaknya tau sendiri.Temen-temen saya yang cowok waktu materi lain mereka mungkin ga memperhatikan, tapi kalo masalah HIV, semua focus. (I think that is a theme which gets so many responses from my friends. I think you understand it. My male students may not pay attention in other themes, but for HIV, all of the students were focus)" 
Students' perception toward their own capability and confidence in the Foreigner's Class

The analysis about this perception was very important since the good interaction class also influenced by the students' capability and confidence in facing the foreigner class. Some students felt enjoy to communicate with the foreigner. They did not feel anxious or nervous. Basically it depended on the personality of each student. They who actually were active students could enjoy the class and understood the foreigner's explanation. They could give good contribution during the class.

In the other side, some students who were active in other class could not be assured that they would also be active in the conversational class taught by the foreigner, as mentioned in Data 31 and Data 32. They did not know how to say or express it in English. These students felt anxious of making mistake so that other people would not understand it. They were also afraid it would be a reason for other students to laugh at them.

(38): “Grogi lah mbak.Ya gimana ya, terkadang sih berani gitu kalau takut salah atau kurang dipahami gitu lo. (I am nervous if I make mistake or speak miss understandable)" (C2.25C2.26)

(39): "Yang grogi takut.Karena ya kurang bisa berbicara bahasa inggris gitu lo. Nanti malah di anu (diejek) temen.(I feel nervous because I cannot speak English well. I am afraid of getting ridicule from others)" (E2.22-25) 


\section{Students' difficulties in having taught by foreigner counterpart}

Having taught by foreigner counterpart with all of different aspects from the both side was not easy, especially for the first year students of SMA Muhammadiyah (Plus) Salatiga. The difficulties and problems appeared although both of them had tried to adjust their selves during the class. Those difficulties could be concluded as follows.

\section{Communication problem}

The differences of background of knowledge, culture and language mostly triggered communication problem. Some misunderstandings and uncomfortable feelings in communication could hinder in realizing an effective teaching and learning process. Most students faced this difficulty. It was caused by the foreigner's incapability to speak in Bahasa Indonesia and less ability of the students in understanding the foreigner's words.

(40): “(Kesulitan utama) Komunikasinya.Ya ada yang karena cepet ngomong, ada yang karena ga paham artinya.Ga, ga jelas sih, terlalu cepet. (The main problem is the communication. He speaks too fast so sometimes we do not understand his words. It doesn't clear enough.)"

( 41): "Kurang memahami bahasa inggris. Kalau ga bisa bahasa inggris itu memahami apa yang dia katakan itu agak sulit. (It is difficult for me to understand his words because I haven't mastered English yet)"

( 42): "Mesti bingung kalau foreigner bicara terus ku ga tau artinya. Terus gimana ini. Kan kalau dia ngomong kita juga berusaha tahu apa yang dia bicarakan gitu to. Kalau ga tau ya... ya masalah utamanya itu aku ga tahu artinya itu. 
Bingung. Kita mau ngomong apa juga ga bisa, trus mau komentar apa juga ga tahu, pendapat apa juga ga tahu. (I feel a little bit confuse when I do not know the meaning of the foreigner's words. We try to understand what he is talking about. However, the problem is I do not know the meaning. As the result I will not be able to give appropriate feedback or comment or opinion)"

\section{Poor classroom management}

Most of students claimed that the foreigner in their conversational class could not manage the class well. The poor classroom management influences the students' reaction and behavior during the class that could trigger subsequent problem such as unconducive class.

This problem was faced not only by students but the foreigner as well. Unfortunately, those various methods and materials could not be accepted for all of students well. As confirmed by the foreigner, the big gradation of the students' ability was the main factor. For the high students, the class was easy enough to be followed. However, for some very weak students it was difficult even to handle the simplest tasks. When the foreigner prepared the class for the weak students, it would be too easy and annoying for the high ones. Another result, the foreigner had given too difficult task for the weak students, so that they could not fulfill it. Then, the middle level also could not fully satisfy both sides. It also became another obstacle for the foreigner itself.

\section{Big class}

The conversational class was divided into two classes, X A and X B which each class consisted of 26 students. Unfortunately, the two classes 
were joined to be one in the conversational class. Although some students did not attend the class, it still became an immersion class. In a conversational class taught by foreigner, too many students surely became a problem.

(43): "Saya juga kurang sreg nya itu, kita gabung sama anak-anak yang rame gitu lo mbak. (The joined class makes me uncomfortable because we have to gather with noisy students) (H2.57)

(44): "Kurang memperhatikan aja soalnya kebawa suasana. Kan itu 2 kelasnya di gabung jadi satu otomatis yang ribut ikutan yang ribut yang anteng juga anteng. (I cannot pay much attention because of classroom atmosphere. The two classes are joined into one, so they will very noisy.)" (C2.49-C2.50)

\section{Unconducive class}

This kind of condition was an effect from the poor classroom management and big class. It absolutely became a serious problem for those who were enthusiastic and serious in joining the class.

(45): “Masalahnya itu sebenarnya ya kalo saya mendengarkan yang disampaikan foreigner tu kayaknya bisa cuman tementemennya itu ada yang berisik jadi kurang konsentrasi. (If I listen carefully to the foreigner I think I can understand. The problem is my friends are too noisy so it is difficult for me to get concentration)"

(46): "Keganggu sama teman yang ga mendengarkan. Ga kondusif. (The noisy students truly disturb me. It is unconducive class)" 


\section{Bad schedules}

The schedule of the conversational class itself also became other problem for some students. There were diligent students who were never absent from the conversational class. However, they who did not attend the class have many reasons. Some students played truant because they were lazy for attending the class. Others blame the inappropriate schedule. The schedule for this extracurricular was on the same time with their own schedule. One of students, for example, admitted that he never came to the class on Friday because he had to do the other things. It was a real because in the fact he attended the conversational class when it was changed on Saturday.

(47): "Kalau yang dulu kan sehabis jumat, dan saya tidak ikut. Karena kan kalau dipanti itu harus jumatan di panti, naaah mulainya kan habis jumatan kalau kesini lagi itu ga sempat.(I cannot attend the class because it is Friday. On Friday we have to pray Jum'at in the orphanage, and if I come back to school again it will be very late)"

(48): "Segi jamnya mungkin. Kan waktu awalan dulu kan hari jumat itu sekitar jam 1 jam 2 itu kan anak-anak uda pada cape. (The problem is the schedule I think. In the past it was in the afternoon on Friday at 1 or 2 p.m., when the students are tired enough)"

Every student had their own ideal time for the schedule of the conversational class. Some of them preferred having a class on Friday to Saturday. However, the other students were on the opposite one. The main thing was an appropriate schedule had to be arranged to create an effective teaching and learning process. 


\section{Conclusion}

The students' perceptions toward conversational class taught by foreigner counterpart are very various. They have their own opinion with its strong reasons. For some students it is a new experience which gives them unforgettable experience. Through many kinds of teaching methods and attractive materials the foreigner can give fun learning for the students. These most of the students give high appreciation with the presence of foreigner in their class.

However, for a few students, the presence of foreigner in their class is not a special thing. For them the most important thing is not about foreign teacher or Indonesian one. Whoever the teacher, they highlight that the more crucial thing is how the teacher can manage the class well. Good classroom management which triggers fun learning is their main consideration. So they do not consider the presence of foreigner as special thing.

Whereas, those who do not like the foreigner's class agree that the personality of the foreigner is the main cause. The foreigner is considered as a temperamental person. The students claimed that their fun learning turns to be bored or strained when the foreigner is getting angry. Then, poor classroom management which triggers unconducive class becomes the additional reason to dislike the foreigner's class.

Furthermore, new experience in the foreigner's class raises some difficulties. They are (a) communication problem. It is claimed as the biggest problem where most students cannot understand the foreigner's words. They also cannot give an appropriate feedback since they do not know how to communicate with the foreigner well. This problem widens 
gaps between them; (b) poor classroom management. This kind of weakness enables some students to make noise during the class. The students will be difficult to concentrate; (c) big class. The conversational class consists of too many students since the two classes are joined as one; (d) unconducive class. This situation is a result of poor management classroom and big class. This unconducive class disturbs those who want to pay attention seriously; (e) bad schedule. Some students claimed that the conversational class itself is scheduled in inappropriate time. It even disables the students to attend the class; (f) cross cultural understanding. Poor understanding of local cultures from the foreigner may become constraint in class. Inappropriate ways to deliver sensitive topics may embarrass some group of students that may cause failure in teaching.

\section{References}

Adediwura, and Tayo, B. 2007. Perception of Teacher Knowledge, Attitude, and Teaching Skills as Predictor of Academic Performance in Nigerian Secondary Schools. Educational Research and Review Vol. 2 (7), July, 2007. Pp: 165-171

Miles, Matthew, B., Michael, H. 1992 Analisis Data Kualitatif: Buku Sumber Tentang Metode-Metode Baru.Jakarta: Penerbit Universitas Indonesia (UI-Press).

Pringgawidagda, S. 2002. Strategi Penguasaan Berbahasa. Yogyakarta: Adicita Karya Nusa.

Stern, H.H. 1992. Issues and Options in Language Teaching.Oxford University Press. 
Students' Perceptions toward a Conversational Class Taught By Foreigner Counterpart 